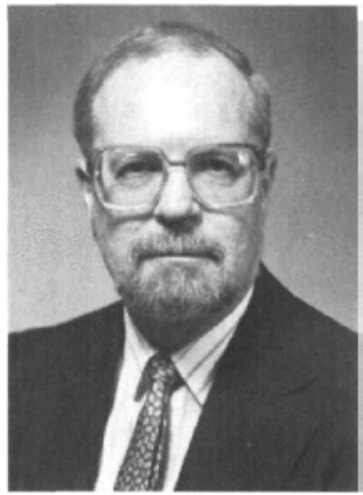

Canadian

Anaesthetists' Society Medal

\title{
La Médaille de la Société Canadienne des Anesthésistes
}

\section{John G. Wade BS MD FRCPC}

Professionalism in medicine implies two essential attributes, beyond specialization of practice: the desire to seek new knowledge, and the desire to transmit to others the knowledge so generated. Dr. John Wade of Winnipeg has consistently contributed in a professional manner to the specialty of Anaesthesia in Canada throughout his career. It was with pleasure and appreciation that the Canadiar. Anaesthetists' Society Medal was presented to Dr. Wade at the 1987 Annual Meeting in Calgary.

A native of Winnipeg, Dr. Wade began his college education at the University of North Dakota in conjunction with a hockcy career with the UND "Fighting Sioux." To our good fortune he returned to Canada to obtain his M.D. degree at the University of Manitoba. Following two years in general practice in Taber, Alberta, he returned to Manitoba to begin postgraduate training in Internal Medicine, but was diverted to Anaesthesia and the Cardiovascular Research Institute at the University of California, San Francisco. Under the tutelage of Dr. Stuart Cullen, Dr. Wade acquired a special ability to link the basic physiologic sciences to the clinical instruction and practice of anaesthesia, in addition to an appreciation of the potential expanded role of anaesthesia within the field of medicine.

Within three years of Dr. Wade's return to the University of Manitoba in 1969, he became Professor and Chairman of the Department of Anaesthesia which subsequently, under his direction, grew to a department of excellence. Following completion of a ten-year term as Department Chairman he was appointed to the position of Vice-President, Medical at the Health Sciences Centre in Wintipeg, at the time the third largest health care institution in Canada. In 1982 he assumed the position of
En plus de la spécialisation dans la pratique, le professionnalisme en médecine comporte deux caractéristiques essentielles: la volonté d'aller en quête de nouvelles connaissances, et la volonté de transmettre aux autres les connaissances ainsi acquiscs. Pendant toute sa carrière, le docteur John Wade, de Winnipeg, a régulièrement contribué de façon professionnelle à la spécialité de l'anesthésie au Canada. C'est avec plaisir et reconnaissance qu'on a décerné la médaille de la Société canadienne des anesthésistes au docteut Wade, en 1987 lors de la réunion ansuelle à Calgary.

C'est a la Universily of North Dakota que le docteur Wade commença ses études universitaires conjointement à une carrière de hockey avec les "Fighting Sioux" de l'UND. Heureusement pour nous, il revint au Canada pour l'obtention de son diplôme M.D. à l'Université du Manitoba. Après deux années de pratique générale à Taber, Alberta, il revint au Manitoba afin d'entreprendre un programme de formation supérieure en médecine interne, mais it bifurqua vers San Francisco au anesthésie et le Cardiovascular Research Institute à l'Université de Califomie. L'enseignement du Dr Stuart Cullen lui fit acquérir une compétence particulière à unir les sciences physiologiques fondamentales à l'enseignement clinique et à la pratique de l'ancsthésic, ainsi qu'une sensibilisation à la possibilité que l'anesthésie puisse jouer un plus grand rôle en médecine.

Moins de trois ans après son retour à l'Université du Manitoba en 1969, le docteur Wade ful nommé professeur et directeur du département d'anesthésie qui, sous sa direction, devint par la suite un département d'excellence. Après un mandat de dix ans comme directeur du département, on lui confia le paste de vice-président médical au 
Dean of the Faculty of Medicine, University of Manitoba. He has led the Faculty through the difficult financial times shared by all Canadian universities, and has remained dedicated to the importance of excellence in patient care and teaching and of the essential nature of research in both clinical medicine and the basic sciences.

On the national and international scenes, his contribution has been no less significant. He served as President of the Manitoba Division of the Canadian Anaesthetists' Society, and chaired several committees for both Canadian and American anaesthesia organizations. He has served the Royal College of Physicians and Surgeons of Canada as an examiner, Chairman of the Anaesthesia Specialty Committee, and member of the Specialty Program Accreditation Committee. He is a Past-President of the Association of Canadian University Departments of Anaesthesia, Chairman of the Standing Committee on Research of the Association of Canadian Medical Colleges, and a Research Advisor to the Canadian Heart Foundation and Health and Welfare Canada. He has been a consultant or visiting professor to most Canadian departments of anaesthesia, and is recognized for his ability to identify the basics of problems and to suggest the most logical and relevant solutions.

Through this time his scientific contribution has been considerable. He has authored more than 35 original research papers on topics ranging from cardiovascular physiology to cerebral resuscitation. More significantly he has been the catalyst and advisor to many successful Canadian investigators. He has been invited to present refresher course lectures to numerous audiences, including the Canadian Anaesthetists' Society, the American Society of Anesthesiologists and regional meetings. He delivered the Royal College lecture at the 1981 Annual Meeting of the Canadian Anaesthetists' Society, and was honoured to be the first Stuart C. Cullen Visiting Professor at the University of Califomia, San Francisco in 1984. One year later he was presented the Sioux Award, the highest bestowed on alumni by the University of North Dakota. This award was in recognition of his efforts in developing a new spirit of cooperative medical education between the University of Manitoba and the University of North Dakola. The same year he hosted the celebration of the 25 th anniversary of the Medical Research Council of Canada, a symposium of significance to the future of medical research in Canada. His contribution has been consistently at the "leading edge" of each of education, practice and research, those triple values of medical professionalism.

But this career was not developed, as so many are, at the expense of personal or family life. John is known for his continued dedication to the quality of the life he shares with Marilyn and his children Frank and Marianne. His
Health Sciences Center à Winnipeg, qui était à ce moment-là au troisième rang des institutions de santé au Canada. En 1982, il devint Doyen de la Faculté de médecine de l'Université du Manitoba. C'est sous sa direction que la Faculté réussit à passer à travers les moments financiers difficiles partagés par toutes les univesités canadiennes, et il continua à se dédier à l'importance de l'excellence dans les soins aportés aux patients et dans l'enseignement ainsi que dans la nature essentielle de la recherche en médecinc clinique et en sciences fondamentales.

Sur la scène nationale et internationale, sa contribution est tout aussi importante. Il fut président de la branche manitobaine de la Société canadienne des anesthésistes, et i1 fut président de plusieurs comités d'organisations anesthésiques canadiennes et américaines. Il fut examinateur au Collège royal des médecins et chirurgiens du Canada, président du Comité de la spécialité d'anesthésie, et membre du Comité d'accréditation pour les programmes de spécialité. Il est un des anciens présidents de l'Association des départements d'anesthésie d'Universités canadiennes, président du Comité permanent de la recherche faisant partie de l'Association des Universités médicales canadiennes, et Conseiller de recherche à la fondation canadienne du couur et à Santé et Bien-Etre Canada. Il fut consultant ou professeur invité dans la plupart des départements d'anesthésie au Canada, et il est reconnu pour son babileté à identifier les problèmes fondamentaux et à offrir les solutions les plus logiques et les plus pertinentes.

Dans tout ce temps, sa contribution scientifique a été considérable. Il est l'auteur de 35 articles originaux sur la recherche portant sur des sujets allant de la physiologie cardiovasculaire à la réanimation cérébrale. De façon plus importante, il a été le catalyseur et le conseiller de plusieurs investigateurs canadiens dont la carrière fut une réusssite. On l'a invité à donner des conférences sur des cours de mise à jour à de nombreux auditoires y compris ceux se trouvant aux réunions de la Société canadienne des anesthesistes, de l'American Society of Anesthesiologists et aux réunions régionales. En 1981, il fut le conférencier représentant le Collège royal à la Réunion annuelle de la Société canadienne des anesthésistes, et en 1984, il fut honoré en tant que premier Stuart C. Cullen Visiting Professor à ]'Université de Californie, San Francisco. Un an plus tard, on lui présenta le Sioux Award, le prix le plus important octroyé aux anciens étudiants de l'Université de North Dakota. Ce prix lui fut décerné en reconnaissance des efforts qu'il a mis à former un nouvel esprit de coopération dans l'enseignement médical entre l'Université du Maniroba et l'Université du North Dakota. Cette même année, il fut l'hôte des festivités du 25 ième anniversaire du Conseil canadien de 
"retreat" at Minaki is unassailable by his work, as is his love for hockey, cross-country skiing, and the personal solitude of a lonely jog home from work. While he has taught us much through the years, probably nothing is as important as the demonstration that one can combine a successful career with a rewarding personal life. In so doing he still leads the anaesthetic and university communities through the troubled times of the 1980's.

The Canadian Anaesthetists' Society is pleased to recognize Dr. John $G$. Wade, a true professional, by the awarding of the Society Medal.

\section{P.G.D.}

Saskatoon la recherche médicale, un symposium de grande importance pour l'avenir de la recherche médicale au Canada. Sa contribution a toujours été à la fine pointe de chacune des trois valeurs du professionnalisme médical c'est-àdire l'enseignement, la pratique et la recherche.

Mais, contrairement à plusieurs carrières, celle-ci n'a pas évolué aux dépens de la vię perșonnẹllẹ ou de la vie familiale. On sait très bien que John se dévoue sans cesse à la qualité de vie qu'il partage avec Marilyn et ses enfants Frank et Marianne. Sa "retraite" à Minaki, son amour du hockey, du ski de fond et de la solitude personnelle que lui apporte le retour à la maison au pas de course, aucune de ces choses ne peut être dérangée par son travail. Il est probable qu'aucune des choses qu'il nous a enseigné pendant toutes ces années ne soit aussi importante que celle démontrant qu'il est possible d'avoir une carrière couronnée de succès et une vie personnelle comblée. Ce faisant, il mène encore les communautés anesthésiques et universitaires à travers les périodes troubles des années 1980.

C'est avec plaisir que la Société canadienne des anesthésistes reconnaît un vrai professionnel en la personne du docteur John $G$. Wade et lui déceme la Médaille de la Société. 